\title{
POTENTIAL UTILITY OF HYPERBARIC OXYGEN THERAPY AND PROPOLIS IN ENHANCING THE LEISHMANICIDAL ACTIVITY OF GLUCANTIME
}

Diana Copi AYRES(1), Thiago Antonio FEDELE(2), Maria Cristina MARCUCCI(2) \& Selma GIORGIO(1)

\begin{abstract}
SUMMARY
In this study we investigated the efficacy of hyperbaric oxygen (HBO) therapy, alone or combined with the pentavalent antimonial glucantime on Leishmania amazonensis infection. In parallel, the effect of Brazilian red propolis gel (propain) alone or combined with glucantime on L. amazonensis infection was evaluated. The inhibition of the infection in macrophages treated with glucantime in combination with $\mathrm{HBO}$ exposition was greater than that of macrophages treated with glucantime alone or $\mathrm{HBO}$ alone. The susceptible mouse strain BALB/c infected in the shaved rump with L. amazonensis treated with glucantime and exposed to HBO showed: time points in the course of the disease in which lesions were smaller than those of mice treated with glucantime alone and revascularization of the skin in the lesion site; interferon-gamma (IFN- $\gamma$ ) levels were not elevated in lymph node cells from these animals. Propain alone was not efficient against lesions, although less exudative lesions were observed in animals treated with propain alone or combined with glucantime. These results reveal the potential value of $\mathrm{HBO}$ and red propolis in combination with glucantime for treating cutaneous leishmaniasis and encourage further studies on the effect of more aggressive HBO, propolis and glucantime therapies on different mouse models of leishmaniasis.
\end{abstract}

KEYWORDS: Leishmania amazonensis; Pentavalent Antimonial; Hyperbaric Oxygen; Propolis; Macrophage; Mouse.

\section{INTRODUCTION}

Leishmaniasis is a neglected disease caused by a protozoan of the genus Leishmania; it is currently endemic in 88 countries ${ }^{11,25}$. The severity of the disease induced by different Leishmania species varies enormously, ranging from cutaneous or mucosal to visceral or diffuse cutaneous infection ${ }^{15}$. Chemotherapy remains the mainstay for the control of leishmaniasis, as effective vaccines have yet to be developed ${ }^{16}$. The pentavalent antimonial $\left(\mathrm{Sb}^{v}\right)$ glucantime has been the basis of leishmaniasis therapy worldwide for over 50 years, achieving remarkable clinical improvements, despite its failure to provide a parasitological cure and its side effects ${ }^{1,8}$.

In the search for new alternative therapies we have recently reported that hyperbaric oxygen (HBO) therapy, which is the application of pressures greater than 1 ATA to an environment of $100 \% \mathrm{O}_{2}^{18}$, reduced the size of $L$. amazonensis-induced footpad lesions in BALB/c mice, while Brazilian Northeastern red propolis tested as an extract was capable of reducing the parasite load in the in vitro L. amazonensis infection of macrophages ${ }^{4}$. Various compounds have been tested, combined with glucantime, in order to improve chemotherapy ${ }^{7,9,14,21-23,26,28,30,34}$, and the rationale behind combining drugs and therapies allows the reduction of treatment duration, resulting in fewer side effects and fewer delays in the development of resistance ${ }^{8,34}$. This report describes the effect of the combined therapy of $\mathrm{HBO}$ and glucantime against intracellular amastigotes in vitro and against infection in mouse model BALB/c. The activity of Brazilian red propolis gel and glucantime against infection in the BALB/c model was also evaluated. The choice of the mouse model infected with $L$. amazonensis in the shaved rump was due to its development of cutaneous lesion closely correspondent to the clinical setting which allows for topical application to the skin ${ }^{19}$.

\section{MATERIALS AND METHODS}

Mice: Inbred BALB/c mice, 6-8 weeks of age, were purchased for the mouse breeding facility at Universidade Estadual de Campinas, Campinas, Brazil. All animal experiments were conducted in accordance with institutional guidelines in compliance with the recommendations of the Guide for the Care and Use of Laboratory Animals.

Parasite and infection of mice: L. amazonensis (MHOM/ $\mathrm{BR} / 73 / 2269$ ) amastigotes were isolated from skin lesions of susceptible mice as previously described ${ }^{3,6}$. BALB/c mice were infected with $1 \mathrm{X}$ $10^{5}$ amastigotes suspended in $20-50 \mu \mathrm{L}$ of sterile saline by subcutaneous injection into the shaved rump. Lesions were measured weekly in two perpendicular diameters with a dial caliper at weekly intervals ${ }^{19}$ and 
AYRES, D.C.; FEDELE, T.A.; MARCUCCI, M.C. \& GIORGIO, S. - Potential utility of hyperbaric oxygen therapy and propolis in enhancing the leishmanicidal activity of glucantime. Rev. Inst. Med. Trop. Sao Paulo 53(6): 329-34, 2011.

were expressed by the dimensions of the nodule base (width by length). The mice were also regularly examined to detect cutaneous ulcers and secondary lesions.

Histological studies: Skin lesion tissues were fixed by immersion in $4 \%$ paraformaldehyde in $0.1 \mathrm{M}$ PBS/0.1M sucrose for $6 \mathrm{~h}$ and processed for standard paraffin embedding ${ }^{3}$. Tissue sections $(5 \mu \mathrm{m})$ were stained with haematoxylin and eosin (H\&E) and checked for pathological changes under an optical microscope (Eclipse E800-Nikon).

Treatment of mice using hyperbaric oxygen and glucantime: Mice caged in groups of six were exposed to $100 \% \mathrm{O}_{2}$ at a pressure of 2.5 ATA for one hour per day in a small animal hyperbaric chamber (Research Chamber, model HB 1300B, Sechrist, CA, USA). The chamber was pressurized and decompressed at the rate of 0.5ATA. Glucantime ( $N$-methyl glucamine antimoniate; Aventis, SP, Brazil) at $27 \mathrm{mg} \mathrm{Sb} /$ $\mathrm{kg} /$ day was injected via intraperitoneal once a day for 20 days after $L$. amazonensis inoculation.

Treatment of mice using red propolis and glucantime: Red propolis was collected in the state of Alagoas, Brazil ${ }^{5,33}$. The ethanolic extracts of propolis were prepared as described by AYRES et al. ${ }^{4}$. The red propolis (2.5\%) gel containing protease (propain) and a protease gel without propolis as a control ${ }^{12}$ were used for epicutaneous applications in the lesions twice or three times a day for 20 days after L. amazonensis inoculation. Glucantime at $27 \mathrm{mg} \mathrm{Sb} / \mathrm{kg} /$ day was injected via intraperitoneal once a day for 20 days after L. amazonensis inoculation.

Cytokine measurements: Inguinal lymph-nodes were excised from animals and single-cell suspensions prepared in Dulbecco-modified minimal essential medium (Sigma Chemical, USA) containing $10 \%$ fetal bovine serum and antibiotics. Cells were plated in triplicate in 24-well culture plates at $4 \times 10^{6} / \mathrm{mL}$ stimulated with $2.5 \mu \mathrm{g} / \mathrm{mL}$ Concanavalin A (Con A) (Sigma Chemical, USA) for $48 \mathrm{~h}$ at $37{ }^{\circ} \mathrm{C}$ with $5 \% \mathrm{CO}_{2}$ in the atmosphere ${ }^{3}$. The levels of interferon-gamma (IFN- $\gamma$ ), and interleukin 4 (IL-4) of the supernatants were determined by an enzyme-linked immunosorbent assay kit according to the manufacturer's instructions (Biolegend, CA, USA).

Infection of macrophage cultures: Primary mouse macrophages were obtained from normal BALB/c mice by peritoneal lavage, cultured on 24-well plates containing glass coverslips of $13 \mathrm{~mm}$ diameter and infected with a sixfold excess of amastigotes as previously described ${ }^{2}$. After the infection period, the cultures were washed to remove extracellular parasites and then submitted to different treatments at $37^{\circ} \mathrm{C}$ in $5 \% \mathrm{CO}_{2}$ in air in a humidified incubator. For the infection evaluation (percentage of infected macrophages and number of amastigotes per macrophage), the cells on the coverslips were stained with Giemsa and examined by light microscopy at a magnification of $1,000^{2}$.

Statistical analyses: In vitro experiments were performed at least three times in triplicate wells. Two to three independent experiments, involving 6-7 mice per group, were performed to analyze drug efficacy. Statistical analyses were performed using the two-tailed Student's $t$-test and Microcal Origin 6.0 (Microcal Software), $p<0.01$ for in vitro experiments and $p<0.05$ for in vivo experiments. A two-way ANOVA followed by the Bonferroni test was used to compare treatments in mice over time.

\section{RESULTS}

We first addressed the question of whether HBO leishmanicidal activity in an amastigote-macrophage model for L. amazonensis is potentiated in combination with glucantime. As shown in Figure 1 and recently for our group ${ }^{2}$ macrophage cultures exposed to $\mathrm{HBO}$ exhibit a significant reduction in the percentage of infected cells and the number of amastigotes per cell as opposed to macrophage cultures not exposed to HBO. The effect of glucantime on infected cells was similar to HBO (Fig. $1)$. The inhibition of the number of amastigotes per macrophage reached $66 \%$ in cells treated with glucantime in combination with exposure to $\operatorname{HBO}(2.1 \pm 0.32$ vs. $5.9 \pm 0.9)$, which is slightly greater than that of either glucantime or $\mathrm{HBO}$ alone (3.9 \pm 0.7 and. $4.2 \pm 0.6)$ (Fig. 1).
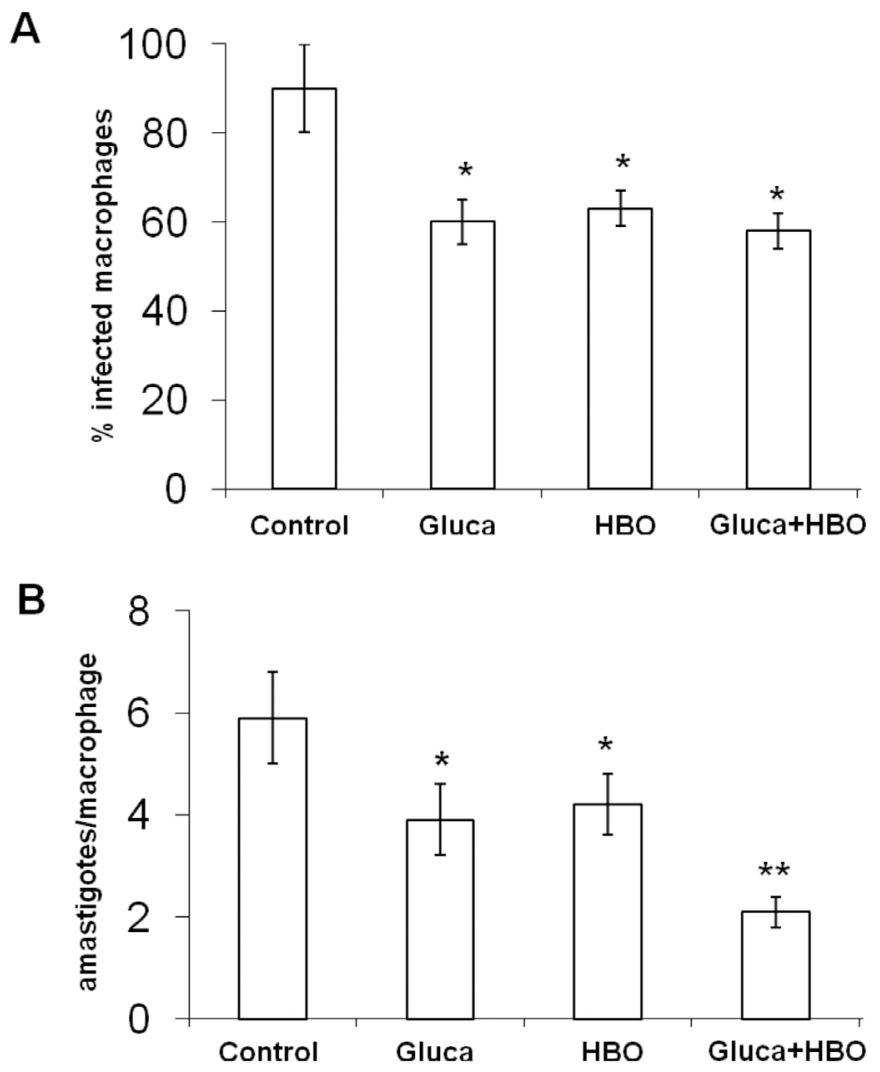

Fig. 1 - Effect of HBO and glucantime on macrophages infected with L. amazonensis. The mouse peritoneal macrophages were infected with amastigotes and cultured for $24 \mathrm{~h}$ (Control), treated with glucantime $(6 \mu \mathrm{g} \mathrm{Sb} / \mathrm{mL})$ for $24 \mathrm{~h}$ (Gluca), exposed to HBO (2.5 ATA, 100\% $\mathrm{O}_{2}$ ) for $2 \mathrm{~h}$ and then cultured for $22 \mathrm{~h}(\mathrm{HBO})$ or exposed to $\mathrm{HBO}$ for $2 \mathrm{~h}$ and then treated with glucantime $\left(6 \mu \mathrm{g} \mathrm{Sb} b^{+5} / \mathrm{mL}\right)$ for $22 \mathrm{~h}($ Gluca+HBO$)$. A. Percentage of infected macrophages. B. Number of intracellular amastigotes per macrophage. The results represent the mean \pm SD of three experiments. * represents statistical differences $(p<0.01)$ between Control, Gluca and HBO. ** represents statistical differences $(p<0.01)$ between Gluca, HBO and Gluca+HBO

The increase of glucantime's leishmanicidal efficacy by combining glucantime with exposure to $\mathrm{HBO}$ was measured in experiments using the BALB/c model infected with L. amazonensis in the shaved rump. One hundred percent of mice had ulcerations after six weeks of infection and their lesions failed to heal. These lesions were elevated and expanded with central ulceration over the next 14 weeks. The treatments started 


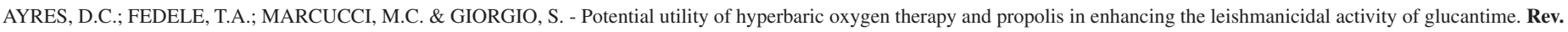
Inst. Med. Trop. Sao Paulo 53(6): 329-34, 2011.

six weeks after infection when skin lesion ulcerated and continued for 20 days. As shown in Figure 2, lesions progressively increased in size in untreated mice. Interestingly, $\mathrm{HBO}$ treatment, although relatively effective in the BALB/c model infected with L. amazonensis in the footpad $^{3}$ (data not shown), was not active in this mouse model infected in the shaved rump (Fig. 2). In comparison, in mice treated with glucantime the lesions did not enlarge during the period of therapy; in fact, they were smaller after the end of therapy and ulceration developed slowly (Fig. 2 ). In the case of animals treated with both glucantime and exposure to $\mathrm{HBO}$, lesions also did not enlarge during the period of therapy. Although lesion size did not differ over time among animals both treated with glucantime and exposed to HBO and animals treated with glucantime alone, there are points in the course of the disease in which significant differences between lesion size and external appearance were observed (nine to 12 weeks after infection; Figs. 2 and 4).

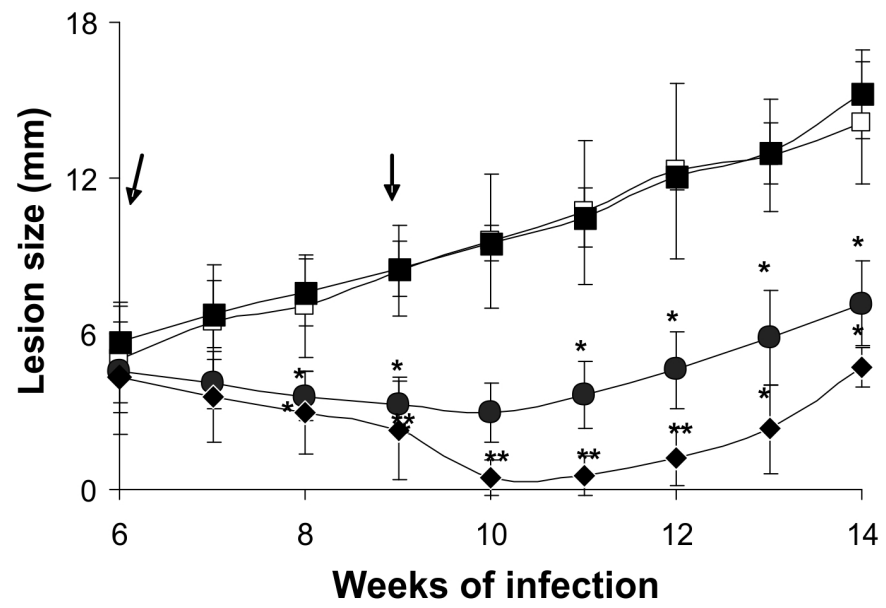

Fig. 2 - Effect of HBO and glucantime on lesion development in BALB/c mice infected with L. amazonensis. Animals were inoculated in the shaved rump with $1 \mathrm{X} 10^{5}$ amastigotes. After six weeks of infection, mice were treated intraperitoneally with saline $(\boldsymbol{\square})$, glucantime (27 $\mathrm{mg} / \mathrm{Sb}^{+5} / \mathrm{kg} /$ day) ( ), exposed to $\mathrm{HBO}\left(2.5 \mathrm{ATA}, 100 \% \mathrm{O}_{2}, 1 \mathrm{~h} /\right.$ day $)(\square)$ or exposed to HBO and treated with glucantime $\left(27 \mathrm{mg} / \mathrm{Sb}^{+5} / \mathrm{kg} / \mathrm{day}\right)(\diamond)$ for 20 days. Representative data from one of three experiments are shown. * represent statistical differences $(p<0.05)$ between saline, glucantime and glucantime + HBO. ** represent statistical differences $(p<0.05)$ between glucantime and glucantime $+\mathrm{HBO}$. Arrows indicate the beginning and end of the treatments.

We also investigated whether the efficacy of glucantime treatment is potentiated by gel containing red propolis (propain). After lesions were established (six weeks) animals were treated for 20 days with glucantime and/or the epicutaneous application of propain. Figure 3 shows that, in mice treated with propain alone, lesions progressively enlarged, similar to lesions of untreated mice. In contrast, glucantime prevented lesion growth during and immediately (two weeks) after treatment, and ulceration developed slowly. The treatment with glucantime and propain prevented lesion development, although ulceration restarted slowly. No significant difference was found in lesion size among animals treated with both glucantime and propain and animals treated with glucantime alone. Interestingly, in mice treated topically with both propain and glucantime, lesions were less exudative than those in non-treated or glucantime treated mice, during the time of observation in the course of the infection (14 weeks). It should be noted that the topical preparation of propain did not elicit apparent

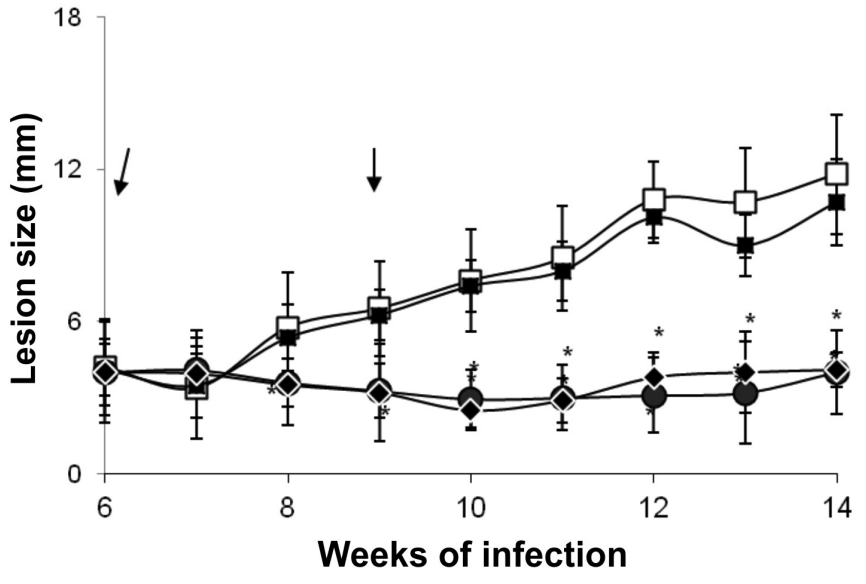

Fig. 3 - . Effect of propain and glucantime on lesion development in BALB/c mice infected with L. amazonensis. Animals were inoculated into the shaved rump with $1 \times 10^{5}$ amastigotes. After six weeks of infection, mice were treated topically with propain ( $\square$ ), gel without propolis $(\square)$, intraperitoneally with glucantime $\left(27 \mathrm{mg} / \mathrm{Sb}^{+5} / \mathrm{kg} / \mathrm{day}\right)(-)$ or glucantime $\left(27 \mathrm{mg} / \mathrm{Sb}^{+5} / \mathrm{kg}\right.$ / day) + propain $(\diamond)$, for 20 days. The results represent the mean \pm SD of three experiments. * represents statistical differences $(p<0.05)$ between propain, gel without propolis + glucantime and glucantime + propain. Arrows indicate the beginning and end of the treatments.

toxicity; the skin was not irritated or inflamed and the surrounding skin did not lose hair.

Histopathological analyses revealed that in the lesions of untreated mice there was no epithelial tissue in the center of the ulcer and the cellular infiltrate consisted predominantly of parasitized and vacuolated macrophages (Fig. 4A and 4B). In contrast, lesions from mice treated with glucantime presented tissue reorganization involving the restructuring of epithelial tissue. There were very few infected macrophages and fewer infiltrating cells than in lesions of untreated mice (Fig. 4C and 4D). After exposure of the lesions to $\mathrm{HBO}$, the histological pattern was similar to that described for lesions of untreated mice (Fig. 4E and 4F), although a process of revascularization of skin took place in the lesion site (Fig. 4F). The lesions of animals both treated with glucantime and exposed to $\mathrm{HBO}$ presented a pattern similar to that of lesions of mice treated with glucantime alone and a process of revascularization of skin (Fig. 4L and 4M). The lesions of animals treated with glucantime and epicutaneous application of propain presented tissue reorganization, intact pilous follicles and skin glands, and few infected macrophages; a pattern similar to that of lesions in mice treated with glucantime alone (Fig. 4G and 4H). The lesions of animals treated with the epicutaneous application of propain alone presented a pattern similar to that of lesions in untreated mice (Fig. 4I and 4J).

To analyze whether the therapies tested induce immune responses, we measured the levels of IFN- $\gamma$ and IL- 4 production by ConAstimulated lymph node cells. It was observed that infected untreated mice produced higher levels of IFN- $\gamma$ compared to mice treated with glucantime alone or treated with both glucantime and exposure to $\mathrm{HBO}$ $(8,200 \pm 250$ vs. $1,059 \pm 145$ vs. $100 \pm 31$; Fig. 5$)$. It was observed that mice treated with both glucantime and propain produced higher levels of IFN- $\gamma$ than mice treated with glucantime alone $(3,090 \pm 122$ versus $1,059 \pm 145$; Fig. 5). No detectable levels of IL-4 were found in cell cultures of mice untreated or treated with glucantime, propain or exposed to HBO (data not shown). 

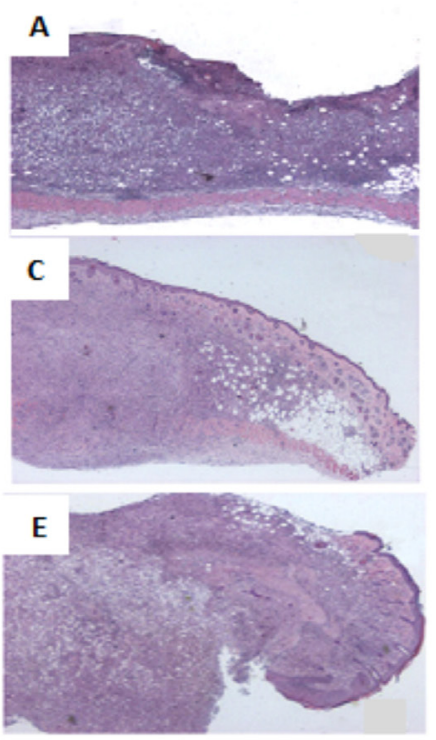

G
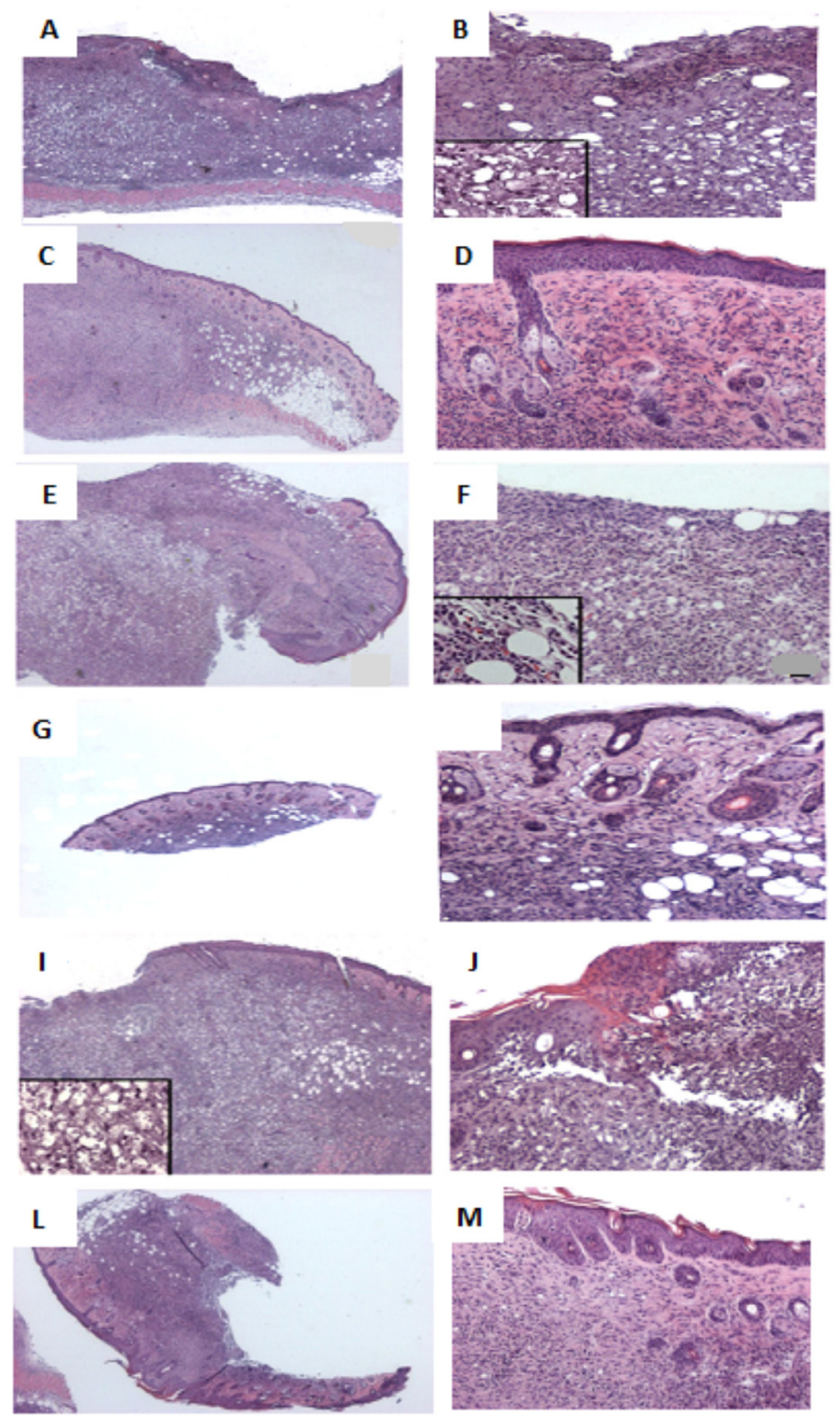

Fig. 4 - Photomicrographs of skin lesions in BALB/c mice infected with L. amazonensis and treated with both glucantime and exposure to HBO. After 10 weeks of infection, histopathological examination revealed no epithelium tissue and many parasitized macrophages in the lesions of untreated mice, X20 (A) and X100 (B); tissue organization and very few infected macrophages in the lesions of mice treated with glucantime, X20 (C) and X100 (D); pathologic alterations observed in the lesions of mice exposed to HBO, X20 (E) and X100 (F) were similar to those observed in the lesions of untreated mice. Inset show blood vessels. Tissue organization and very few infected macrophages are shown in the lesions of mice treated with both propain and glucantime, X20 (G) and X100 (H) or treated with propain alone, X20 (I) and X100 (J). Insets show parasitized macrophages. Tissue organization in the lesions of mice both exposed to HBO and treated with glucantime, X20 (L) and X100 (M).

\section{DISCUSSION}

The combination of chemotherapy for treatment of leishmaniasis and other infectious diseases has been addressed in latter years ${ }^{7,9,14,21-23,26,30,32,34}$. Recently, we showed that HBO is toxic for L. amazonensis promastigotes and can reduce macrophage susceptibility to infection and the size of

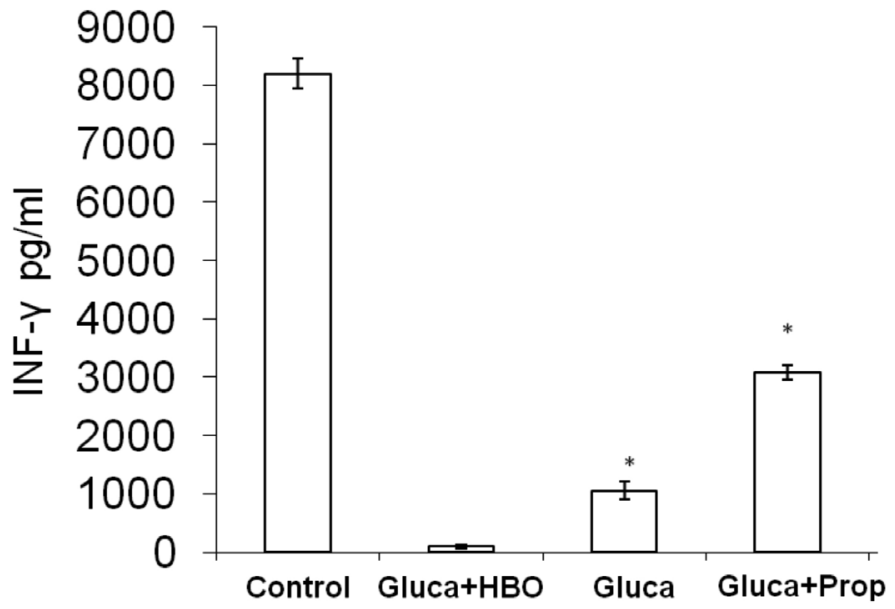

Fig. 5 - INF- $\gamma$ production in BALB/c mice infected with L. amazonensis and treated with glucantime, propain or exposure to HBO. Supernatants from ConA-stimulated draining of lymph node cells from untreated mice (Control), treated with glucantime (Gluca), glucantime and exposure to $\mathrm{HBO}$ (Gluca+HBO) or glucantime and propain (Gluca+Prop) were assayed by INF- $\gamma$ production by ELISA. The results represent the mean \pm SD of independent repeats. * represents statistical differences $(p<0.01)$ between the Control and Gluca, Gluca+HBO and Gluca+Prop.

footpad lesion in BALB/c mice ${ }^{2,3}$. In the present study, the inhibition of the infection in macrophages treated with glucantime in combination with $\mathrm{HBO}$ was greater than that of macrophages treated with glucantime alone and $\mathrm{HBO}$ alone. The exact mechanism by which glucantime combined with $\mathrm{HBO}$ was more effective in the in vitro macrophage model is not known. Based on our previous reports ${ }^{2}$ and literature data ${ }^{10,13}$ we suggest that free radicals and other reactive oxygen-based molecules produced by macrophages and parasites under HBO cannot be adequately detoxified by parasites treated simultaneously with glucantime. Antimonials inhibit trypanothione reductase enzymatic system, which protect against oxidative damage ${ }^{13}$.

The in vivo model studies showed that there are points in the course of the disease in BALB/c mice treated with both glucantime and exposure to $\mathrm{HBO}$ in which lesions are smaller than those in mice treated with glucantime alone. This may be an indicator that HBO is having a small but significant impact in improving glucantime efficacy. Indeed, animals exposed to $\mathrm{HBO}$ exhibited skin revascularization in the lesion site which could facilitate glucantime delivery. Previous reports have shown in wound mouse models ${ }^{27,31}$, transplanted rats ${ }^{31}$, and rat liver after partial hepatectomy ${ }^{17}$ that neovascularization is increased in animals exposed to HBO. To analyze whether the therapies induce immune responses, INF- $\gamma$ and IL-4 levels were measured. The INF- $\gamma$ level produced by ConA-stimulated draining lymph node cells of infected mice is as high as that also reported by BARROSO et al. ${ }^{7}$, but a reduction of INF- $\gamma$ was observed in animals treated with glucantime, which is attributed to the inhibition of the parasite burden in lesions, i.e. the source of INF- $\gamma$ stimulus ${ }^{7,24}$. Interestingly, a marked-down regulation of INF- $\gamma$ was also observed when mice were both treated with glucantime and exposed to HBO; which also could be related to the reduction of parasites in the lesions.

The other objective of this study was to evaluate the activity of red propolis combined with glucantime treatment. Once we had already 
shown the anti-parasite effect of ethanolic extracts of red propolis in promastigotes and in L. amazonensis infected macrophages ${ }^{4}$, we tested red propolis gel (propain) on mouse model BALB/c. The treatment with both propain and glucantime was similar to the treatment with glucantime alone, i.e. lesion growth is prevented for two weeks after treatment and smaller lesions than those in untreated mice are present until the end of the experiment. However, less exudative lesions were observed in animals treated with propain alone or combined with glucantime. Propain alone was not effective against L. amazonensis lesions. Various pharmacological effects have been attributed to propolis, such as antiviral, antibacterial and analgesic ${ }^{29,33}$ effects. The red propolis extract studied in this report reduced the dissemination of melanoma cells in mice ${ }^{12}$. The reasons for our results are not known. BALB/c mice cutaneously infected with L. amazonensis represent a model of extreme susceptibility and a string test for chemotherapy displaying rapid development of skin lesions followed by ulceration and cutaneous metastases resembling human cutaneous diffuse leishmaniasis. No cure was obtained with glucantime $e^{6,20}$.

In conclusion, the results presented in this report reveal the potential value of $\mathrm{HBO}$ and red propolis in combination with glucantime for treating cutaneous leishmaniasis and encourage further studies on the effects of more-aggressive HBO, propolis and glucantime therapies in different mouse models of leishmaniasis.

\section{RESUMO}

\section{A utilidade da terapia de oxigenação hiperbárica e própolis em potencializar a atividade leishmanicida do glucantime}

Nesse trabalho foi avaliada a eficácia da terapia da oxigenação hiperbárica (HBO), aplicada em combinação ou não com o tratamento com glucantime, durante a infecção com Leishmania amazonensis. $\mathrm{O}$ efeito de gel da própolis vermelha de origem brasileira (propaina) aplicado em combinação ou não com o tratamento com glucantime, também foi avaliado durante infecção com esse parasita. A inibição da infecção de macrófagos tratados com glucantime em combinação com $\mathrm{HBO}$ foi maior que a de macrófagos tratados apenas com glucantime ou HBO. A linhagem murina susceptível, BALB/c, infectada no dorso com L. amazonensis, tratada com glucantime e exposta a HBO, mostrou durante o curso da doença, fases em que as lesões eram menores do que a de camundongos apenas tratados com glucantime; observou-se revascularização da pele da lesão e baixa produção de interferon-gama em células de linfonodos desses animais. O tratamento com propaina não foi eficiente na cura das lesões, apesar de lesões menos exsudativas serem observadas em animais tratados com propaina ou propaina combinada ao tratamento com glucantime. Os resultados demonstram que tanto HBO como a própolis vermelha em combinação com glucantime, são promissoras no tratamento da leishmaniose cutânea. Novos estudos devem ser realizados para avaliar tratamentos e outros protocolos em diferentes modelos murinos da leishmaniose.

\section{ACKNOWLEDGEMENTS}

This work was supported by the Fundação de Amparo à Pesquisa do Estado de São Paulo, Conselho Nacional de Desenvolvimento Cientifico e Tecnológico and the Coordenação de Aperfeiçoamento de Pessoal de Nível Superior, Brazil.

\section{AUTHOR CONTRIBUTIONS}

D.C. Ayres and T.A. Fedele carried out the experiments, M.C. Marcucci carried out the experiments and the analyses of results and SG conceived of the study and wrote the manuscript.

\section{REFERENCES}

1. Alvar J, Croft S, Olliaro P. Chemotherapy in the treatment and control of leishmaniasis. Adv Parasitol. 2006;61:223-74.

2. Arrais-Silva WW, Collhone MC, Ayres DC, De Souza Souto PC, Giorgio S. Effects of hyperbaric oxygen on Leishmania amazonensis promastigotes and amastigotes. Parasitol Int. 2005;54:1-7.

3. Arrais-SilvaWW, Pinto EF, Rossi-Bergmann B,Giorgio S. Hyperbaric oxygen therapy reduces the size of Leishmania amazonensis-induced soft tissue lesions in mice. Acta Trop. 2006;98:130-6.

4. Ayres DC, Marcucci MC, Giorgio S. Effects of Brazilian propolis on Leishmania amazonensis. Mem Inst Oswaldo Cruz. 2007;102:215-20.

5. Ayres DC, Marcucci MC, Giorgio S. Treatment methods of leishmaniasis with Brazilian propolis. Requested patent. Brazilian National Institute for Intelectual Property, INPI n ${ }^{\circ}$ PI 018060007317,01/27/2006, 2006.

6. Barão SC, Giorgio S. Efficacy of 8-bromoguanosine against murine cutaneous leishmaniasis induced with Leishmania amazonensis. Chemotherapy. 2003;49:159-62.

7. Barroso PA, Marco JD, Calvopina M, Kato H, Korenaga M, Hashiguchi Y. A trial of immunotherapy against Leishmania amazonensis infection in vitro and in vivo with Z-100, a polysaccharide obtained from Mycobacterium tuberculosis, alone or combined with meglumine antimoniate. J Antimicrob Chemother. 2007;59:1123-9.

8. Berman JD. Current treatment approaches to leishmaniasis. Curr Opin Infect Dis $2003 ; 16: 397-401$.

9. Bouguila J, Chabchoub I, Moncef Y, Mlika A, Saghrouni F, Boughamoura L, et al. Traitement dy syndrome d'activation macrophagique severe associé à une leishmaniose viscérale. Arch Pediatr. 2010;17:1566-70.

10. Daruwalla J, Greish K, Nikfarjam M, Millar I, Malcontenti-Wilson C, Iyer AK, et al. Evaluation of the effect of SMA-pirarubicin micelles on colorectal cancer liver metastases and of hyperbaric oxygen in CBA mice. J Drug Target. 2007;15:487-95.

11. Desjeux P. Leishmaniasis: current situation and new perspectives. Comp Immunol. Microbiol Infect Dis. 2004;27:305-18.

12. Fedele TA, Andrades NED, Marumo KT, Marcucci MC, Maria DA. Evaluation of the antitumoral activity of red propolis in association with a protease in melanoma. Applied Cancer Res. 2007;27:125-6.

13. Frézard F, Demicheli C, Ribeiro RR. Pentavalent antimonials: new perspectives for old drugs. Molecules. 2009;14:2317-36.

14. Gangneux JP, Sulahian A, Garin YJ, Derouin F. Efficacy of aminosidine administered alone or in combination with meglumine antimoniate for the treatment of experimental visceral leishmaniasis caused by Leishmania infantum. J Antimicrob Chemother. 1997;40:287-9

15. Grimaldi G Jr, Tesh RB. Leishmaniasis of the New World: current concepts and implications for future research. Clin Microbiol Rev. 1993;6:230-50.

16. Handman E. Leishmaniasis: current status of vaccine development. Clin Microbiol Rev. 2001;14:229-43. 
AYRES, D.C.; FEDELE, T.A.; MARCUCCI, M.C. \& GIORGIO, S. - Potential utility of hyperbaric oxygen therapy and propolis in enhancing the leishmanicidal activity of glucantime. Rev Inst. Med. Trop. Sao Paulo 53(6): 329-34, 2011.

17. Ijichi H, Taketomi A, Yoshizumi T, Uchiyama H, Yonemura Y, Soejima Y, Shimada M, et al. Hyperbaric oxygen induces vascular endothelial growth factor and reduces liver injury in regenerating rat liver after partial hepatectomy. J Hepatol. 2006;45:28-34.

18. Kaide CG, Khandelwal S. Hyperbaric oxygen: applications in infectious disease. Emerg Med Clin North Am. 2008;26:571-95.

19. McElrath MJ, Kaplan G, Nusrat A, Cohn ZA. Cutaneous leishmaniasis. The defect in T cell influx in BALB/c mice. J Exp Med. 1987;165:546-59.

20. Miguel DC, Yokoyama-Yasunaka JK, Uliana SR. Tamoxifen is effective in the treatment of Leishmania amazonensis infections in mice. PLoS Negl Trop Dis. 2008;2:e249.

21. Monzote L, Montalvo AM, Scull R, Miranda M, Abreu J. Combined effect of the essential oil from Chenopodium ambrosioides and antileishmanial drugs on promastigotes of Leishmania amazonensis. Rev Inst Med Trop Sao Paulo. 2007;49:257-60.

22. Mutizo JM, Macharia JC, Barasa M, Taracha E, Bourdichon AJ, Gicheru MM. In vitro and in vivo antileishmanial efficacy of a combination therapy of diminazene and artesunate against Leishmania donovani in Balb/c mice. Rev Inst Med Trop Sao Paulo. 2011;53:129-32.

23. Padrón-Nieves M, Díaz E, Machuca C, Romero A, Ponte Sucre A. Glibenclamide modulates glucantime activity and disposition in Leishmania major. Exp Parasitol. 2009; 121: 331-7.

24. Qi H, Ji J, Wanasen N, Soong L. Enhanced replication of Leishmania amazonensis amastigotes in gamma interferon-stimulated murine macrophages: implications for the pathogenesis of cutaneous leishmaniasis. Infect Immun. 2004;72:988-95.

25. Reithinger R, Dujardin JC, Louzir H, Pirmez C, Alexander B, Brooker S. Cutaneous leishmaniasis. Lancet Infect Dis. 2007;7:581-96.

26. Salmanpoor R, Bahmani M. Comparison between intralesional glucantime plus steroid and glucantime in the treatment of cutaneous leishmaniasis. Hormozgan Med J. 2007;11:26.
27. Sander AL, Henrich D, Muth CM, Marzi I, Barker JH, Frank JM. In vivo effect of hyperbaric oxygen on wound angiogenesis and epithelialization. Wound Repair Regen. 2009;17:179-84.

28. Serrano-Martín X, Payares G, De Lucca M, Martinez JC, Mendoza-Léon A, Benaim G. Amiodarone and miltefosine act synergistically against Leishmania mexicana and can induce parasitological cure in a murine model of cutaneous leishmaniasis. Antimicrob Agents Chemother. 2009;53:5108-13.

29. Sforcin JM, Bankova V. Propolis: is there a potential for the development of new drugs? J Ethnopharmacol. 2011;133:253-60.

30. Solgi G, Kariminia A, Abdi K, Darabi M, Ghareghozloo B. Effects of combined therapy with thalidomide and glucantime on leishmaniasis induced by Leishmania major in BALB/c mice. Korean J Parasitol. 2006;44:55-61.

31. Stiegler P, Matzi V, Pierer E, Hauser O, Schaffellner S, Renner H, et al. Creation of a prevascularized site for cell transplantation in rats. Xenotransplantation. 2010;17:37990

32. Taylor PL, Wright GD. Novel approaches to discovery of antibacterial agents. Anim Health Res Rev. 2008;9:237-46.

33. Trusheva B, Popova M, Bankova V, Simova S, Marcucci MC, Miorin PL, et al. Bioactive constituents of Brazilian red propolis. Evid Based Complement Alternat Med. 2006;3:249-54

34. Van Griensven J, Boelaert, M. Combination therapy for visceral leishmaniasis. Lancet. 2011;377:443-4

Received: 14 August 2011

Accepted: 28 September 2011 